\title{
Izzivi zgodnje obravnave predšolskih otrok
}

\author{
Karmen Drljić \\ Univerza na Primorskem \\ karmen.drljic@pef.upr.si
}

Sodobno razumevanje zgodnje obravnave otrok izhaja iz sistemsko-ekološke teorije, ki omogoča poglobljeno prepoznavanje rizičnih dejavnikov v otrokovem razvoju in njegovem okolju. Namen zgodnje obravnave je zagotoviti ustrezno preventivo ter pravočasno obravnavo otroka, ki izkazuje posebnosti v razvoju, tj. že v najzgodnejšem obdobju njegovega življenja. V začetku leta 2019 je v Sloveniji stopil v veljavo Zakon o celostni zgodnji obravnavi predšolskih otrok s posebnimi potrebami, ki naj bi to področje celostno uredil. Zanimalo nas je, kako svetovalni delavci vrtca razumejo pomen zgodnje obravnave, kakšne prednosti in slabosti zaznavajo $v$ omenjenem zakonu ter kako v njem prepoznavajo svojo vlogo. Z dvema svetovalnima delavkama smo opravili intervju. Ugotovili smo, da novi zakon prinaša številne prednosti na področju zgodnje obravnave, a tudi izzive. Slednji se nanašajo predvsem na sodelovanje z različnimi akterji, ki so vključeni v zgodnjo obravnavo. Poudarjata, da še niso zagotovljeni vsi pogoji, da bi zakon udejanjali.

Ključne besede: svetovalni delavci, zakon, otroci s posebnimi potrebami, vrtec, zgodnja obravnava

\section{Uvod}

Razumevanje koncepta zgodnje obravnave ( $v$ nadaljevanju ZO) temelji na sistemsko-ekološki teoriji (Soriano 2005) ter sloni na sodobnem razumevanju (nevrološkega) razvoja dojenčkov, malčkov in otrok (Krek in Metljak 2011). Ekosistemski model omogoča razumevanje kompleksnosti odnosov in različnih situacijskih okoliščin v otrokovem okolju (Bronfenbrenner 1995). Omogoča tudi razumevanje, na kakšen način potekajo interakcije med otrokom in okoljem ter kako le-te prispevajo k njegovemu razvoju (Renn 2003). Razumevanje kompleksnosti okolja in bolj ali manj zapletenih interakcij med njim ter otrokom lahko prispeva k oblikovanju okolja, ki spodbudno vpliva na otrokov razvoj in učenje (Renn 2003). Ekosistemska teorija temelji na dveh ključnih predpostavkah. Prva pravi, da je otrokov razvoj odvisen od čedalje kompleksnejših in recipročnejših interakcij med aktivnim in razvijajočim se posameznikom (torej otrokom) ter drugo osebo, objektom in simbolom, ki se nahaja v njegovem neposrednem okolju (Bronfenrenner 1995). Druga predpostavka pa pravi, da so bližnje neposredne interakcije odvisne od otrokovih lastnosti, njegove razvojne stopnje ter neposrednega in posrednega okolja.

Čotar Konrad, S., B. Borota, S. Rutar, K. Drljić in G. Jelovčan, ur. 2022. Vzgoja in izobraževanje predšolskih otrok prvega starostnega obdobja. Koper: Založba Univerze na Primorskem.

(c) Br.sA https://doi.org/10.26493/978-961-293-134-6.169-188 
Razumevanje ZO z ekosistemskega vidika omogoča celostno in poglobljeno prepoznavanje rizičnih dejavnikov tveganja v otrokovem razvoju, ki so lahko posledice njegovih razvojnih posebnosti in/ali specifičnosti neposrednega in posrednega okolja, znotraj katerega se razvija, ter pravočasno in učinkovito ciljno naravnano obravnavo.

\section{Opredelitev zgodnje obravnave}

Porter (2002 v Soriano 2005) ZO, ki je osnovana na ekosistemski teoriji, opredeli $s$ holističnega, $z$ dinamičnega, $s$ transakcijskega in posamičnega vidika. Holistični vidik pomeni, da otroka v okviru ZO obravnavamo celostno, tako da skrbimo za vsa področja njegovega razvoja, to je: kognitivno, govornojezikovno, telesno, socialno-čustveno. Dinamični vidik izpostavlja pomen spreminjanja okolja glede na vedno se spreminjajoče se potrebe otroka. Transakcijski vidik poudarja pomen recipročnega odnosa medsebojnega vplivanja med otrokom in drugo odraslo osebo, v okviru katerega se oba razvijata. Posamični vidik pa pomeni, da je otrok individuum in sta zato njegov proces izgrajevanja znanja in njegov razvoj glede na druge specifična oz. edinstvena (Porter 2002 v Soriano 2005).

Namen ZO je spodbuditi otrokov razvoj ter delovati preventivno pri preprečevanju ali zmanjševanju zaostanka v razvoju (Majnemer 1998). Začne se ob rojstvu otroka in se zaključi ob njegovem vstopu v šolo (Globačnik 2012). Sicer pa so otroci s primanjkljaji, z motnjami oz. s težavami deležni specialnoinkluzivne strokovne pomoči tudi po vstopu v šolo. L. Marjanovič Umek in M. Zupančič (2009 v Globačnik 2012) sta mnenja, da lahko ZO sega že v prenatalno obdobje, torej $v$ obdobje od spočetja do rojstva. Za to obdobje in obdobje od dojenčka do malčka (o-3 let) je značilno, da ZO poteka v okviru zdravstvenih služb. V obdobju od dojenčka do malčka je lahko prisotna tudi pedagoško-rehabilitacijska obravnava (Marjanovič Umek in Zupančič $2009 \mathrm{~V}$ Globačnik 2012). Slednje je otrok deležen tudi v obdobju zgodnjega otroštva (3-6 let). S. Fillis, L. Dunne in B. McConnell (2018) na podlagi različnih študij ZO omejijo na obdobje od dojenčka do malčka, saj se v njem najpogosteje kažejo prve razvojne posebnosti in zaostanki v razvoju.

\section{Značilnosti zgodnje obravnave}

ZO je namenjena otrokom in njihovim družinam, pri katerih so prisotni biološki in/ali socialni dejavniki tveganja (Globačnik 2012). Otrok in njegova družina sta deležna ZO, ko je pri njiju prepoznana težava, ne pa tudi v primeru prepoznanega tveganja zanjo (Globačnik 2012). Ločimo dve skupini otrok, ki jim je ZO namenjena, to so: (1) rizični otroci in (2) otroci s primanjkljaji, mo- 
tnjami oz. težavami (Majnemer 1998). Za skupino rizičnih otrok je značilno, da so mlajši od treh let in je prisotno tveganje za nadaljnji razvoj na kognitivni, gibalni, komunikacijski ter čustveni ravni otrokovega delovanja (Globačnik 2008). V skupino otrok s primanjkljaji, motnjami in težavami pa uvrščamo otroke s senzornimi okvarami, z gibalno oviranostjo in motnjami v duševnem razvoju. Pri teh otrocih so primanjkljaji, motnje oz. težave dokaj zgodaj prepoznane. Po drugi strani A. Majnemer (1998) navaja tri skupine otrok, ki so lahko deležne pomoči in podpore v okviru ZO:

- otroci, ki so ranljivi zaradi depriviligiranih razmer v fizičnem in socialnem okolju,

- otroci, ki so ranljivi zaradi specifičnih bioloških dejavnikov (npr. nedonošenost, fetalni alkoholni sindrom, hipoksija),

- otroci s prepoznano motnjo, primanjkljajem ali težavo, ki pomembno vpliva na otrokov razvoj.

S. Fillis, L. Dunne in B. McConnell (2018) so identificirale sedem oblik ZO: (1) ZO v programih predšolske vzgoje, (2) ZO, usmerjene $v$ družine otrok s posebnimi potrebami, (3) ZO, usmerjene v razvoj govorno-jezikovnih zmožnosti, (4) ZO, usmerjene v kognitivni razvoj, (5) ZO, usmerjene v socio-emocionalni razvoj, (6) ZO usmerjene v celostni razvoj. Za zagotavljanje ustrezne in učinkovite $Z O$ bi bilo treba zagotoviti ustrezna usposabljanja za strokovne delavce ter skrbeti za dosledno izvajanje podpore in pomoči. Posebno pozornost bi bilo treba nameniti tudi vključenosti družin $v$ ZO z upoštevanjem nekaterih posebnosti, kot so doživljanje zadovoljstva mater, usposobljenost staršev (tudi očetov) za pomoč otrokom v okviru njihovih zmožnosti ter kompetentnost strokovnih delavcev za educiranje staršev in spodbujanje njihove motiviranosti za delo z otrokom (Fillis, Dunne in McConnell 2018).

\section{Pomen, prednosti in izzivi zgodnje obravnave}

M. Nores in Barnett (2011) poudarjata, da je ZO pomemba, saj se zgodaj ciljno usmerja v otroke, ki v obdobju zgodnjega otroštva izkazujejo socialnoemocionalno-razvojne dejavnike tveganja, zato, da bi povečali možnosti za njihov boljši razvoj in boljšo učno uspešnost. Avtorja sta s pomočjo metaraziskave, $v$ katero sta vključila 24 različnih evropskih, azijskih, afriških ter južnoameriških držav, ugotovila, da je ZO otrok v glavnem usmerjena v štiri ključna področja otrokove delovanja in razvoja, in sicer:

- razvijanje kognitivnih zmožnosti otrok, in sicer besedišča, jezika, zgodnjih opismenjevalnih zmožnosti, zgodnjih matematičnih zmožnosti; 
- razvijanje socialno-emocionalnih veščin (samoregulacija, igra, obvladovanje agresivnega vedenja, hiperaktivnosti;

- izboljšanje pogojev za zdravje (telesna teža, prehranjenost, motorične veščine);

- izboljšanje pogojev za vzgojo in izobraževanja (obiskovanje šole, dolžina vključenosti v vzgojo in izobraževanje, zmanjševanje števila osipnikov).

ZO otrok, ki je usmerjena v njihovo skrbstvo ter vzgojo in izobraževanje in ne zgolj v njihovo prehranjenost, ima pozitivne učinke predvsem na razvoj otrokovih kognitivnih zmožnosti. Prav tako so se pozitivni učinki ZO izkazali pri razvoju njegovih socialno-čustvenih veščin (Nores in Barnett 2011). ZO, ki dovolj dolgo traja in je intenzivna ter usmerjena $v$ otrokove potrebe, ima prav tako pozitivne učinke na otrokov razvoj. Pri tem ne smemo zanemariti aktivno-participativne vloge staršev, ki imajo ključno vlogo pri razvoju otroka s prepoznanimi posebnimi potrebami. Starši, ki so izgradili ustrezna znanja in veščine, lahko pomembno prispevajo $\mathrm{k}$ rasti in razvoju otroka (Majnemer 1998).

\section{Zgodnja obravnava v Sloveniji}

Do nedavnega v Sloveniji nismo imeli ustreznega modela ZO otrok s posebnimi potrebami, tako kot so ga imele nekatere druge evropske države (Krek in Metljak 2011). V teh državah je skladno s teoretično opredelitvijo ZO le-ta usmerjena tako $v$ pomoč otroku kot njegovi družini in zajema storitve svetovanja, socialno pomoč, priložnostno varstvo in celostno obravnavo otroka pri različnih strokovnih delavcih. Avtorji Bele knjige (Krek in Metljak 2011) so po zgledu urejenosti ZO v drugih državah prav tako predlagali, da bi bila pomoč usmerjena ne le $v$ otroka, temveč tudi v njegovo družino. Poleg tega pa naj bi poimenovanje otroci s posebnimi potrebami pri otrocih, starih do treh let, nadomestil izraz otroci s pomembnim odstopanjem od značilnega razvoja, razen v primerih, ko je pri otroku motnja, primanjkljaj oz. težava že prepoznana.

V začetku leta 2019 je stopil v veljavo zakon, ki ureja področje ZO predšolskih otrok v Sloveniji. Zakon o celostni zgodnji obravnavi predšolskih otrok $s$ posebnimi potrebami (2017) (v nadaljevanju ZOPOPP) celostno zgodnjo obravnavo otrok $s$ posebnimi potrebami opredeli kot obravnavo otroka in njegove družine $z$ namenom zagotoviti in spodbuditi celosten otrokov razvoj, okrepiti zmogljivost družine in njuno socialno vključenost. Celostna ZO je tako namenjena otrokom s posebnimi potrebami in otrokom z rizičnimi 
dejavniki v predšolskem obdobju. Po ZOPOPP (2017) so otroci s posebnimi potrebami $\vee$ predšolskem obdobju otroci z razvojnimi zaostanki, primanjkljaji, ovirami oz. motnjami na telesnem, spoznavnem, zaznavnem, socialnočustvenem, sporazumevalnem področju ter dolgotrajnimi boleznimi. $\mathrm{S}$ tem se opredelitev otrok s posebnimi potrebami razlikuje od opredelitve $v$ Zakonu o usmerjanju otrok s posebnimi potrebami (ZUOPP-1 2011), ki navaja devet skupin otrok s posebnimi potrebami (npr. otroci z motnjami v duševnem razvoju, gibalno ovirani otroci, dolgotrajno bolni otroci ipd.) in se približuje opredelitvi, ki jo predlaga Bela knjiga (Krek in Metljak 2011). Otroci z rizičnimi dejavniki v predšolskem obdobju so otroci, pri katerih so prisotni rizični dejavniki za razvojne primanjkljaje, zaostanke, ovire oz. motnje. Pri tem so rizični dejavniki tisti, ki:

- nastanejo v pred-, med- ali poporodnem obdobju,

- so posledica bolezni ali

- socio-ekonomskega statusa družine otroka

in vplivajo na otrokov nadaljnji razvoj (ZOPOPP 2017).

Z ZOPOPP (2017) je opredeljeno, da ZO izvajajo centri za zgodnjo obravnavo ( $v$ nadaljevanju CZO) oz. na njihov predlog tudi vrtci, drugi vzgojnoizobraževalni zavodi, socialnovarstveni zavodi, centri za socialno delo, centri za duševno zdravje in svetovalni centri. CZO naj bi delovali v okviru javne mreže, zagotavljali naj bi tudi pokritost posamezne regije. $S$ tem bi zagotovili inkluzivno naravnost (Ainscow, Booth in Dyson 2006) in dostopnost ZO vsem. Znotraj centra naj bi delovali večdisciplinarni timi, ki bi jih tvorili pediater, diplomirana medicinska sestra, srednja medicinska sestra ali administrator, fizioterapevt, delovni terapevt, logoped, psiholog, strokovni delavci s področja specialne in rehabilitacijske pedagogike, socialni delavci ter drugi strokovnjaki (ZOPOPP 2017). V CZO naj bi imel ključno vlogo pediater - ta naj bi otroka glede na prepoznane težave in potrebe usmeril v nadaljnjo obravnavo $\mathrm{k}$ ustreznemu strokovnemu delavcu znotraj centra ali na center za socialno delo. Pediater bo oblikoval tudi večdisciplinarni tim oz. določil strokovne delavce centra, ki bodo vključeni v obravnavo otroka. Večdisciplinarni timi naj bi otrokom in družinam nudili podporo ter pomoč s področja zdravstva, vzgoje in izobraževanja in socialnega varstva (ZOPOPP 2017). Naloge večdisciplinarnega tima bodo zajemale: (1) postavitev diagnoze, (2) oceno zmožnosti in potreb otroka ter njegovih staršev, (3) pripravo individualnega načrta pomoči družini ter spremljanje in evalvacijo le-tega, (4) informiranje staršev o oblikah pomoči in socialnih pravicah, ki jih lahko koristijo, ter (5) pripravo na- 
črta prehoda v vrtec, osnovno šolo ali zavod za vzgojo in izobraževanje otrok s posebnimi potrebami ali socialnovarstveni zavod (ZOPOPP 2017). ZOPOPP (2017) predvideva tudi nov strokovni profil, ki je bil dotlej v slovenskem prostoru neznan. Gre za koordinatorja pomoči družinam. Tudi tega določi pediater. Koordinator pomoči družinam predstavlja nekakšen vezni člen med družino in člani večdisciplinarnega tima $\mathrm{CZO}$, centrom za socialno delo ter $\mathrm{s}$ strokovnimi delavci, ki delajo v programih predšolske vzgoje (ZOPOPP 2017). $\checkmark$ programih za predšolske otroke s prilagojenim izvajanjem in dodatno strokovno pomočjo se lahko v okviru ZO otrokom prilagodi organizacijo in način izvajanja programa ter zagotovi dodatno strokovna pomoč, deležni so lahko tudi fizične pomoči oz. pomoči strokovnega delavca za znakovni jezik ali prilagojeno komunikacijo (ZOPOPP 2017), kar je bilo že do sedaj do določene mere zagotovljeno otrokom s posebnimi potrebami, ki so bili usmerjeni v program s prilagojenim izvajanjem (ZUOPP 2011). Spodbudno je, da ZOPOPP (2017) poleg pomoči otrokom v vrtcu, ki se lahko izvaja v in izven skupine, predvideva tudi pomoč na domu. Poleg CZO je tudi vrtec dolžan oblikovati strokovno skupino za ZO, ki jo sestavljajo svetovalni delavec vrtca, strokovni delavec v oddelku (vzgojitelj) in strokovni delavec za ZO (vzgojitelj za zgodnjo obravnavo), ki sodeluje s koordinatorjem CZO.

\section{Metodologija}

ZOPOPP (2017), ki naj bi celostno uredil področje ZO otrok s posebnimi potrebami, v strokovni javnosti odpira različna vprašanja o svoji izvedbi. Z omenjenim zakonom namreč še niso bili sprejeti podzakonski akti in pravilniki, ki bi v celoti omogočali izvajanje posameznih določil ZOPOPP. Zato je bil naš namen $\mathrm{s}$ študijo primera ugotoviti, $\mathrm{s}$ katerimi izzivi se $v$ tem trenutku srečujejo svetovalni delavci pri uresničevanju ZOPOPP. Natančneje nas je zanimalo, kako svetovalni delavci v splošnem razumejo pomen ZO, kako ocenjujejo pogoje za uresničevanje ZOPOPP ter katere so po njihovem mnenju prednosti oz. slabosti ZOPOPP. Zastavili smo si naslednja raziskovalna vprašanja:

1. Kako svetovalni delavci vrtcev razumejo zgodnjo obravnavo in njen pomen za otroke s posebnimi potrebami?

2. Kako svetovalni delavci $v$ splošnem ocenjujejo pogoje za uresničitev zgodnje obravnave glede na ZOPOPP?

3. Katere prednosti in slabosti svetovalni delavci prepoznavajo $v$ ZOPOPP?

V raziskavi sta sodelovali dve svetovalni delavki z več kot petletnimi delov- 
nimi izkušnjami, ki sta zaposleni v dveh različnih vrtcih na območju primorske statistične regije. $V$ tej statistični regiji naj bila zagotovljena dva CZO.

S svetovalnima delavkama smo izvedli polsturkturirani intervju. Ključna vprašanja smo predhodno oblikovali, pri čemer smo izhajali iz raziskovalnih vprašanj. Vnaprej smo ju prosili za dovoljenje za snemanje intervjuja. Takoj po končanem intervjuju smo naredili transkripcijo zvočnih podatkov. Sledila je kvalitativna obdelava podatkov s programsko opremo Atlas.ti. Podatke smo kodirali ter oblikovali pojme, ki smo jih združili v kategorije. Z analizo sopojavnosti smo znotraj kategorij med posameznimi pojmi iskali povezave. Slednje nam je omogočilo razuvanje ne le, kako se pojmi med seboj (kvalitativno) povezujejo, temveč tudi, kako se medsebojno prepletajo.

\section{Rezultati $\mathbf{z}$ razpravo}

S kvalitativno obdelavo podatkov smo prepoznali 12 pojmov, ki smo jih združili v štiri kategorije, in sicer (1) razumevanje pomena ZO, (2) pogoji za uresničevanje ZO, (3) prednosti ZOPOPP in (4) izzivi uresničevanja ZOPOPP (preglednica 1). Prva kategorija vsebuje le en pojem, ki smo ga poimenovali pomen zgodnje obravnave. Druga kategorija vsebuje dva pojma, to sta nezadostni pogoji za uresničevanje ZOPOPP in nejasnosti glede uresničevanja ZOPOPP. $\checkmark$ tretjo kategorijo smo združili pet pojmov, ti so aktivno vključevanje staršev otrok s posebnimi potrebami, pomoč in podpora staršem otrok s posebnimi potrebami, zagotavljanje celostne obravnave in zagotavljanje pravočasne obravnave. Četrta in zadnja kategorija pa združuje štiri pojme, to so izzivi sodelovanja $z$ različnimi akterji, pomen varnega okolja, usmerjenost $v$ zdravstveno obravnavo in vloga socialnih delavk v ZO. Najpogosteje so bili omenjeni pojmi vloga svetovalnih delavk v ZO (17), izzivi sodelovanja z različnimi akterji (14) ter nejasnosti glede uresničevanja ZOPOPP. Kategorija izzivi uresničevanja ZO vključuje največ citatov (35).

\section{Razumevanje pomena zgodnje obravnave}

Obe svetovalni delavki, vključeni v raziskavo, pričakovano prepoznavata pomen ZO za otroke s posebnostmi v razvoju oz. s posebnimi potrebami. Ena svetovalna delavka je pomen ZO skušala razložiti s prikazom trenutnega stanja oz. stanja do sprejetja ZOPOPP, v katerem svetovalni delavci vrtcev niso imeli dovolj možnosti in pogojev, da bi lahko zagotovili ustrezno obravnavo vseh otrok, ki bi le-to potrebovali:

ZO je zelo pomembna in je bila v dosedanjih okoliščinah in pogojih, ki smo jih imeli, pravzaprav zelo otežena, marsikdaj nismo imeli pogo- 
Preglednica 1 Pogostost pojmov in kategorij

\begin{tabular}{|c|c|c|c|c|c|}
\hline Pojmi & $n$ & $f(\%)$ & Kategorije & $n$ & $f(\%)$ \\
\hline Pomen ZO & 3 & 3,45 & Razumevanje pomena ZO & 3 & 3,66 \\
\hline $\begin{array}{l}\text { Nezadostni pogoji za } \\
\text { uresničevanje ZOPOPP }\end{array}$ & 6 & 6,90 & $\begin{array}{l}\text { Pogoji za uresničevanje } \\
\text { ZO }\end{array}$ & 19 & 23,17 \\
\hline $\begin{array}{l}\text { Nejasnosti glede } \\
\text { uresničevanja ZOPOPP }\end{array}$ & 14 & 16,09 & & & \\
\hline $\begin{array}{l}\text { Aktivno vključevanje } \\
\text { staršev otrok s PP }\end{array}$ & 3 & 3,45 & Prednosti ZOPOPP & 25 & 30,49 \\
\hline $\begin{array}{l}\text { Obravnava širše skupine } \\
\text { otrok }\end{array}$ & 8 & 9,19 & & & \\
\hline $\begin{array}{l}\text { Pomoč in podpora } \\
\text { staršem otrok s posebnimi } \\
\text { potrebami }\end{array}$ & 5 & 5,75 & & & \\
\hline $\begin{array}{l}\text { Zagotavljanje celostne } \\
\text { obravnave }\end{array}$ & 5 & 5,75 & & & \\
\hline $\begin{array}{l}\text { Zagotavljanje pravočasne } \\
\text { obravnave }\end{array}$ & 4 & 4,60 & & & \\
\hline $\begin{array}{l}\text { Izzivi sodelovanja z } \\
\text { različnimi akterji }\end{array}$ & 14 & 16,09 & $\begin{array}{l}\text { Izzivi uresničevanja } \\
\text { ZOPOPP }\end{array}$ & 35 & 42,68 \\
\hline Pomen varnega okolja & 3 & 3,45 & & & \\
\hline $\begin{array}{l}\text { Usmerjenost v } \\
\text { zdravstveno obravnavo }\end{array}$ & 5 & 5,75 & & & \\
\hline $\begin{array}{l}\text { Vloga svetovalnih delavk v } \\
\text { zgodnji obravnavi }\end{array}$ & 17 & 19,54 & & & \\
\hline Skupaj & 87 & 100,00 & Skupaj & 82 & 100,00 \\
\hline
\end{tabular}

jev, da bi se lahko pri vseh otrocih, ki imajo take težave, ZO lahko sploh izvajala.

Tudi druga svetovalna delavka meni, da je ZO otrok pomembna zaradi ranljivosti in občutljivosti le-teh v najzgodnejšem obdobju njihovega razvoja:

Nam kot vrtcu pa tudi meni osebno se zdi ZO zelo pomembna. V predšolskem obdobju je čisto vsak mesec pomemben za otrokov razvoj in sama se ob zaznavi problematike pri otroku zelo hitro s starši pogovorim, jih usmerim, napotim [...].

Otrokovi možgani so že kmalu po rojstvu, nato pa v celotnem obdobju zgodnjega otroštva podvrženi hitremu razvoju, za katerega so značilna t. i. občutljiva oz. kritična obdobja (Blakemore in Frith 2005). V prvih petih letih otrokovega življenja pa poteka njegov intenzivni kognitivni in čustveno- 
Slika 1

Pogoji za uresničevanje zgodnje obravnave
Pogoji za uresničevanje ZOPOPP

socialni razvoj ter razvoj njegovih samoregulacijskih zmožnosti (Karoly, Kilburn in Cannon 2005). Prav zaradi omenjenega je ZO otrok s posebnimi potrebami oz. posebnostmi v razvoju izredno pomembna, saj lahko s pravočasnim ukrepanjem ter $z$ ustrezno spodbudo in usmerjanjem največ naredimo za njihov nadaljnji razvoj in razvoj njihovih potencialov (Koegel idr. 2014). Zamujene priložnosti v razvoju je namreč mogoče nadoknaditi le do določene mere (Blakemore in Frith 2005). Pri tem so ključne interakcije, ki se vzpostavijo med otrokom in njegovim neposrednim (npr. družina, vrtec) ter posrednim (npr. urejenost ZO) okoljem (Bronfenbrenner 1995; Renn 2003) - tako oblikujejo spodbudno okolje za razvoj. Le usklajeno delovanje omenjenih okolij omogoča učinkovito obravnavo otroka, ki potrebuje dodatno podporo in pomoč.

\section{Pogoji za uresničevanje zgodnje obravnave}

Svetovalni delavki sta poudarili, da je v procesu uresničevanja ZOPOPP še veliko nejasnosti oz. neznank, prav tako še niso uresničeni vsi pogoji, ki bi omogočali neovirano uresničevanje omenjenega zakona. Nezadostni pogoji v svetovalnih delavkah ustvarjajo občutek, da je način izvedbe ZO v okviru ZOPOPP še vedno nejasen (slika 1).

Ena svetovalna delavka je trenutne okoliščine opisala kot zelo negotove in nejasne, saj je znanih premalo informacij o tem, kako se bo ZOPOPP uresničeval:

V trenutni situaciji smo v velikem vakumu - veliko je informacij, malo je potrjenih, ministrstva, ${ }^{1}$ ki so sodelovala pri ZOPOPP, še niso izpeljala potrebnih stvari, da bi lahko zakon zaživel, kljub temu pa je s 1. 1. 2019 stopil v uporabo.

\footnotetext{
${ }^{1}$ Ministrstvo za izobraževanje, znanost in šport, Ministrstvo za zdravje in Ministrstvo za delo, družino, socialne zadeve in enake možnosti, op. avt.
} 
Nejasnosti glede uresničevanja ZOPOPP se nanašajo tudi na definicijo otrok, ki bodo upravičeni oz. deležni podpore in pomoči v okviru ZO. ZOPOPP (2017) namreč predvideva, da je ZO namenjena otrokom s posebnimi potrebami in otrokom $\mathrm{z}$ rizičnimi dejavniki v predšolskem obdobju. Otroke $\mathrm{s}$ posebnimi potrebami v predšolskem obdobju pa definira širše in ne glede na specifične skupine. Pri tem je ena svetovalna delavka izpostavila, da je širša definicija otrok s posebnimi potrebami ali z rizičnimi dejavniki, ki potrebujejo ZO, prednost, ne more pa si še predstavljati, na kakšen način se bo uporaba te definicije uresničevala v konkretnih okoliščinah:

Prednost je $v$ tem, da je tako poimenovanje možno razumeti širše, ker ne določa posameznih kategorij, kar smo videli v preteklosti, kako je bilo, ko še ni bila določena kategorija otroci $z$ avtističnimi motnjami. [...] Če so naštete točno določene kategorije, se lahko zgodi, da otrok ima težave (izpostavila bi npr. otroke s čustveno-vedenjsko problematiko), vendar ne more biti uvrščen v nobeno od teh kategorij. Predvidevamo lahko, da bo v bodoče lažje zajeti več otrok. Vprašanje pa je, kako bo $v$ praksi.

Tudi literatura navaja, da je $v$ predšolskem obdobju smiselno govoriti o področjih, na katerih se posebnosti v razvoju izkazujejo, in ne o posameznih skupinah otrok s posebnimi potrebami (Krek in Metljak 2011; Simpson in Warner 2010).

Druga svetovalna delavka je izrazila zaskrbljenost nad tem, na kakšen način bo potekalo sodelovanje med različnimi akterji, kot so svetovalna delavka centra, zdravnik pediater idr., ki bodo oz. so odgovorni za uresničevanje celostne ZO. Pri tem je izrazila predvsem skrb ob prezgodnjem vključevanju centra za socialno delo $v$ obravnavo otroka, kar bi lahko starše odvrnilo od sodelovanja:

Upam, da bo tim dovolj fleksibilen, da bo znal razbrati, kdaj je za posameznega otroka $v$ določeni fazi obravnave tako sodelovanje koristno in potrebno [...] če sem prav razumela, bodo otroci, ki so obravnavani v vrtcu, obravnavani tudi na CZO. [...] Starše je velikokrat težko pripraviti k sodelovanju, saj že tako težko sprejemajo vso situacijo, sedaj, ko bo vključenih v obravnavo otroka in celotne družine toliko več ljudi, pa je skrb, da bodo starši še težje sodelovali, toliko večja.

Ena svetovalna delavka je tudi poudarila, da ko je v obravnavo otroka vključenih veliko strokovnih delavcev, se lahko zgodi, da to ustvari občutek zme- 
denosti staršev, predvsem takrat, kadar strokovni delavci v svojih stališčih niso poenoteni oz. so le-ta celo diametralno nasprotujoča si:

Postavitev posamezne diagnoze (hiperaktivnost, motnja pozornosti, avtizem) se velikokrat določa na podlagi vedenja, zato so lahko mnenja posameznikh strokovnjakov različna. Zavedati se moramo, da tudi okolje vpliva na vedenje otroka in v skupini, kjer je 24 otrok, je vedenje zagotovo drugačno kot v individualni situaciji (npr. pri pediatru). Starši od različnih strokovnjakov prepogosto dobivajo različne informacije in so zmedeni ter seveda sprejmejo tisto, kar jim je lažje slišati.

Sodelovanje $z$ različnimi strokovnimi sodelavci oz. z večdisciplinarnim timom je za svetovalnega delavca zahtevno tudi $z$ vidika organiziranosti dela in časa, ki ga ima na razpolago za enega otroka:

Sicer se lahko dobimo na sestanku, vprašanje pa je, ali nam bo to časovno uspelo za vse otroke. Glede na to, da imamo kar veliko število obravnavanih otrok (letno najmanj 40), se sprašujem, ali bomo imeli tudi časovne možnosti sprotne izmenjave informacij za vsakega otroka posebej. Velikokrat je problem sploh uskladitev terminov. Skrbi me, da nam bo za sprotno evalvacijo in sprotno izmenjavo informacij $z$ vsemi člani tima zmanjkalo časa. Samo s kontinuiranim delom pa lahko staršem in otroku ponudimo možnost za napredek in razvoj v pravo smer [...]

Po drugi strani pa svetovalna delavka prepoznava tudi prednosti sodelovanja z različnimi akterji, saj bo to lahko priložnost, da poenotijo svoje ugotovitve in stališča ter jih staršem tudi enotno predstavijo:

Prednost novega zakona je tudi ta, da bomo imeli več priložnosti za srečevanje in se bomo lahko pogovarjali in enako tudi staršem predstavljali.

Sodelovanje pa jim bo omogočilo, da z različnih vidikov - tako pedagoškega kot medicinskega - detektirajo otroke, ki potrebujejo ZO, kar pomeni, da bo le-te deležnih več otrok, kot jih je je bilo do sedaj:

Število otrok v obravnavi se bo zagotovo spremenilo, saj mi prepoznavamo nekaj, zdravniki nekaj drugega. Težave se lahko zazna takoj po rojstvu (npr. slabši mišični tonus) ali pa kasneje $v$ otrokovem razvoju (npr. avtizem). Pogosto se zgodi, da v vrtcu nimamo informacije, 
da je otrok obravnavan $v$ razvojni ambulanti in obratno, lahko se pri otroku kaže primanjkljaj na govorno-jezikovnem področju in otrok ne obiskuje razvojne ambulante, vendar mu je $v$ vrtcu nudena pomoč. Pri nas bo nabor otrok, ki bodo obravnavani, večji, hkrati bomo tudi mi večje število otrok, ki jih zdravstvo prej ni obravnavalo, predali zdravstvu oz. skupni obravnavi.

Svetovalni delavki sta poudarili tudi, da trenutno niso zagotovljeni vsi pogoji za udejanjanje določil ZOPOPP, pri čemer sta omenili: odsotnost pravilnika, ki bi podrobneje urejal zakonska določila, še ne oblikovane normative za zaposlitev vzgojiteljev za zgodnjo obravnavo, neopredeljeno financiranje zaposlitev ter pomanjkanje strokovnega kadra v CZO ipd. Vse našteto onemogoča, da bi se v prehodnem obdobju uvajanja ZOPOPP ta lahko v celoti udejanjal in s tem zagotovil pravočasno obravnavo predvsem otrokom $\mathrm{s}$ posebnostmi v razvoju, ki še niso bili usmerjeni v ustrezen program vzgoje in izobraževanja:

Po novem naj bi bili ti postopki krajši, vendar ne vem, koliko je realno, otroci naj bi prej dobili pomoč, vprašanje pa je, kako bodo to kadrovsko zmogli CZO.

Pri tem si predvsem ena svetovalna delavka želi, da bi pediatri, ki so z ZOPOPP osrednji koordinatorji ZO, prisluhnili njihovemu mnenju in predlogom:

Po novem zakonu ob zaznavi težav pri otroku starše usmerimo k pediatru, pediater pa je tisti, ki odloča, ali otroka usmeriti v CZO. Pediater otroka ima torej veliko vlogo pri odločanju in nadaljnji usmeritvi. [...] Upam, da bodo pediatri razumeli, da je obravnava nujna, če smo v vrtcu določeno težavo zaznali. Večkrat se je že zgodilo, da so rekli staršem: počakajte, videli boste, da bo steklo, pustite otroku čas, obravnava trenutno ni potrebna. Otrok v predšolskem obdobju nima časa in vsak mesec brez ustrezne pomoči je velika izguba zanj. Pomembno je, da nam tudi pediatri zaupajo [...].

Ne glede na to, da je pediater osrednji koordinator ZO, je pri tem treba upoštevati, da ta zajema različne vidike otrokovega razvoja in življenja (Globačnik 2012) ter predvideva različne vrste obravnave, ki so bodisi zdravstvene bodisi pedagoške in specialno-rehabilitacijske. Ob tem pa ne smemo zanemariti tudi skrbi za (socialno) inkluzijo otrok s posebnimi potrebami - prav tu je lahko vloga svetovalne delavke vrtca ključna. 


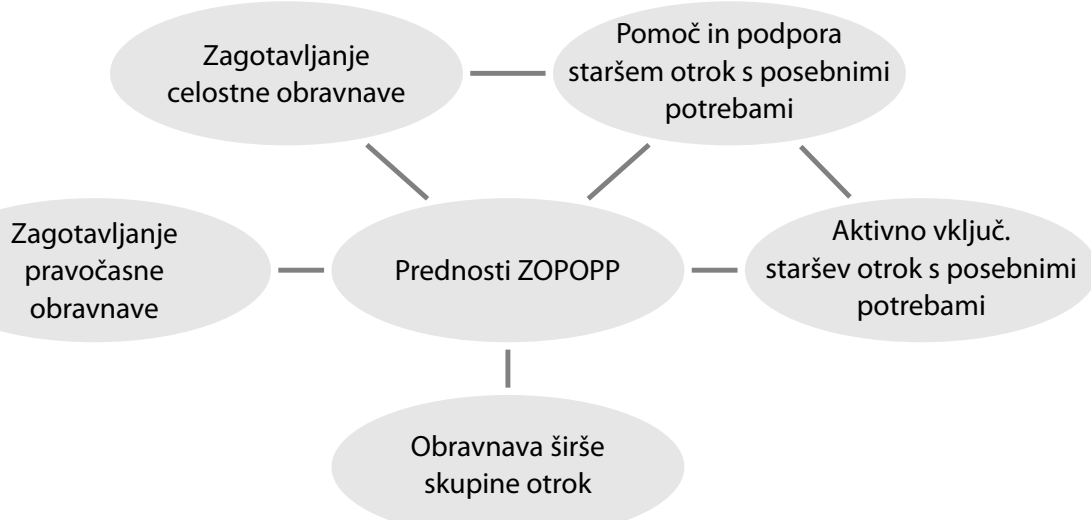

Slika 2 Prednosti ZOPOPP

\section{Prednosti Zakona celostne zgodnje obravnave predšolskih otrok s posebnimi potrebami}

Svetovalni delavki v ZOPOPP prepoznavata tudi različne prednosti. Nekatere, ki jih omenjata, se tudi medsebojno povezujejo in prepletajo (slika 2). Prednost ZOPOPP zagotovo predstavlja pomoč in podpora staršem otrok s posebnimi potrebami, ki se bo uresničevala tudi skozi njihovo večje aktivno vključevanje v celostno ZO. ZOPOPP (2017) namreč predvideva tudi pripravo individualnega načrta pomoči družini, ki ga bodo na CZO tudi sprotno evalvirali. Usmerjenost ZOPOPP v pomoč in podporo družini pa posredno in neposredno zagotavlja tudi celostno obravnavo otroka s posebnimi potrebami. Ozaveščeni starši ter straši, ki so izgradili potrebna znanja in veščine za nudenje ustrezne pomoči in podpore svojim otrokom, lahko pomembno prispevajo $\mathrm{k}$ njihovemu uspešnemu razvoju (Majnemer 1998). Svetovalni delavki kot prednost ZOPOPP navajata tudi zagotavljanje pravočasne obravnave, ki je bo deležna širša skupina otrok, ki zaradi posebnosti v razvoju potrebujejo pomoč.

Prednost ZOPOPP (ki je lahko $v$ tem trenutku lahko še razumljena kot nejasnost) je zagotovo ta, da predvideva obravnavo širše skupine otrok, ki imajo posebne potrebe oz. so pri njihovem razvoju in/ali okolju prisotni rizični dejavniki. Pri tem sta obe svetovalni delavki izpostavili, da ZOPOPP ponuja boljše možnosti, da bodo ustrezno podporo in pomoč dobili tudi otroci, ki izkazujejo čustveno-vedenjske posebnosti. Po ZUOPP-1 (2011) komisija za usmerjanje otrok s posebnimi potrebami oz. otrok s posebnostmi v čustvovanju ter vedenju ni usmerjala $v$ ustrezni program vzgoje in izobraževanja, 
saj se otroci v tem obdobju še niso osebnostno izoblikovani. Ena svetovalna delavka je tako opisala dosedanjo obravnavo otrok s čustveno-vedenjskimi posebnostmi:

V predšolskem obdobju se otrok s čustveno-vedenjskimi motnjami ne usmerja oz. se ne opredeljuje, da imajo na tem področju težave. Mi pa se srečujemo $z$ otroki, pri katerih lahko govorimo, da so prisotne težave na čustveno-vedenjskem področju, ki zahtevajo našo pozornost in obravnavo, da se ne razvijejo $v$ motnje.

Obenem lahko delo z otroki s čustveno-vedenjskimi težavami, ki niso ustrezno obravnavani, pedagoškim delavcem predstavlja vir stresa (Kyriacou 2001), saj nezmožnost obvladovanja vedenj otroka zmanjšuje doživljanje njihove samoučinkovitosti (Tschannen-Morana in Hoy 2007), kar se odraža v njihovem zmanjšanem doživljanju učinkovitosti pri delu z omenjenimi otroki. Ne glede na omenjeno pa velja, da se pri preozko usmerjeni definiciji otrok s posebnimi potrebami oz. posebnostmi v razvoju ter otrok, ki potrebujejo dodatno specifično pomoč in podporo, lahko zgodi, da slednjih niso deležni vsi, ki ju v resnici potrebujejo.

Obe svetovalni delavki sta prednost ZOPOPP prepoznali tudi v zagotavljanju pravočasne ter celostne obravnave, saj bodo $v$ obravnavo vključeni različni strokovnjaki, ki se bodo povezovali v večdisciplinarnem timu, obravnava otroka pa bo potekala na enem mestu:

Imeli bomo več možnosti, da se pogovorimo, si izmenjamo mnenja in otroka tako celostno obravnavamo. Starši pa bodo na enem mestu dobili vse potrebne in koristne ter enotne informacije. [...].

Obenem pa naj bi ZOPOPP predvideval tudi podporo in pomoč družinam otrok s posebnimi potrebami ter aktivno vključevanje staršev pri zagotavljanje podpore in pomoči otroku. Ena svetovalna delavka je povedala naslednje:

Če bodo starši obravnavani v CZO, jim bodo bistveno lažje dostopne vse te storitve, od logopeda, specialno-rehabilitacijskega pedagoga, ki se bodo tam povezovali z razvojno pediatrinjo, delovno terapevtko, $s$ fizioterapevtko in socialno delavko ter delovali usklajeno in bolj učinkovito. Skrbi nas, ali bodo CZO zmogle vse družine voditi in obravnavati na tovrsten način.

Izpostavila je tudi, da bodo lahko starši odslej veliko bolj sodelovali pri obravnavi svojega otroka oz. bili v obravnavo bolj vključeni: 


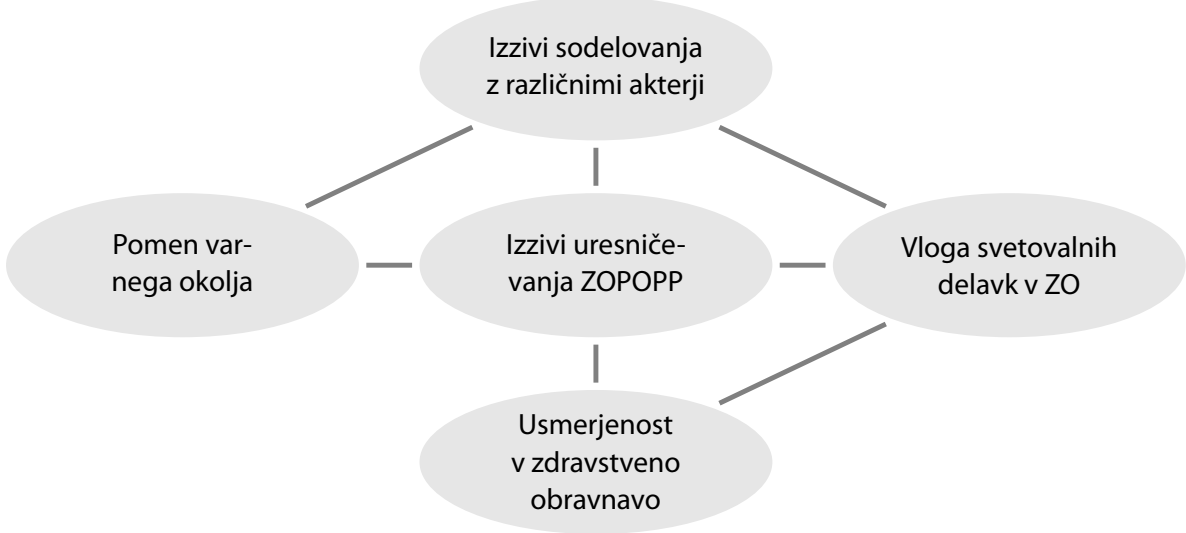

Slika 3 Izzivi uresničevanja ZOPOPP

Bistveno bolj aktivno bodo lahko sodelovali, čeprav po drugi strani starši, ki so bili doslej aktivni, ki so sprejemali naše usmerjanje in vodenje, so lahko tudi sami uspešno prispevali k pomoči svojemu otroku.

Sodelovanje med starši in svetovalnimi delavci mora izhajati iz temeljnega medsebojnega zaupanja. Odnos s starši pa je treba postopno izgrajevati in negovati, tudi s pomočjo neformalnih pogovorov (McWilliam 2010). S tem ko starši zaupajo strokovnemu delavcu, lahko ta podrobneje spozna, na kakšen način deluje družina (Prater 2010). Vključevanje staršev otrok s posebnimi potrebami oz. posebnostmi v razvoju predstavlja tudi enega izmed štirih temeljnih področij kompetenc in vrednot, ki omogočajo zagotavljanje inkluzije in inkluzivne vzgoje ter izobraževanja (Borg idr. 2011), zato je skrb za njihovo (aktivno) sodelovanje ključnega pomena.

\section{Izzivi uresničevanja Zakona celostne zgodnje obravnave predšolskih otrok s posebnimi potrebami}

Svetovalni delavki sta navedli različne izzive, ki jih pred svetovalne delavce vrtca postavlja ZOPOPP. Izzivi, ki jih omenjata, se tudi medsebojno povezujejo in prepletajo (slika 3). Izziv zagotovo predstavlja usmerjenost ZOPOPP $v$ zdravstveno obravnavo - $s$ tem je pod vprašaj postavljena vloga svetovalnih delavk vrtca, istočasno pa so te postavljene pred izziv, kako sodelovati z različnimi strokovnimi delavci, člani večdisciplinarnega tima, izven vrtca ter pri tem zagotoviti okolje, $v$ katerem se starši otrok s posebnimi potrebami počutijo varne.

Eden izmed pomembnejših izzivov, ki sta ga svetovalni delavki navedli, se nanaša na usmerjenost ZO v zdravstvo. Iz ZOPOPP (2017) je namreč razvidno, 
da je težišče obravnave usmerjeno v CZO, v okviru katerega ima razvojni pediater poglavitno vlogo. Ena svetovalna delavka je izrazila zaskrbljenost nad tem pa tudi nad tem, da bo morda svetovalni delavec izgubil svojo temeljno vlogo:

Žal mi je, da se obravnava spet prenaša izven vrtca. Včasih otrok v vrtcu preživi več časa kot doma. V vrtcu se počuti varnega. Tudi starši nam zaupajo. Upam, da bomo tudi svetovalni delavci oz. drugi strokovni delavci vrtca slišani in upoštevani, ker smo prav mi tisti, pri katerih otrok preživi veliko časa in otroka dobro poznamo. Na žalost postajamo člani nekega tima zunaj vrtca, namesto da bi se na vrtce bolj obračali. Želimo si tudi več vključenosti strokovnih delavcev iz CZO v vrtce (v smislu opazovanja otroka v skupini) ter sodelovanja s strokovnimi delavkami v vrtcu.

Z Zakonom o usmerjanju otrok s posebnimi potrebami (ZUOPP-1 2011) smo želeli $\vee$ Sloveniji postaviti pogoje za inkluzijo otrok s posebnimi potrebami in $s$ tem osvetliti razumevanje otrokovih posebnih potreb tudi $z$ vidika okolja, $v$ katerega je vključen. Medicinski vidik razumevanja otrok $\mathrm{s}$ posebnimi potrebami izhaja zgolj iz otrokovih težav, neupoštevajoč okolje. Inkluzivno-socialno-pedagoški vidik razumevanja otroka s posebnimi potrebami pa poudarja, da so posebne potrebe otroka posledica ovir, ki mu jih postavlja okolje (Slee 2014; Pantić in Florian 2015). Pri udejanjanju ZOPOPP bo zato potrebno posebno skrb nameniti tesni povezanosti med medicinskim in inkluzivno-socialno-pedagoškim vidikom razumevanja posebnih potreb (Mitchell 2014).

Vloga svetovalnih delavcev vrtca je, da otroku zagotovijo pravočasno obravnavo tudi glede na to, kar opazijo pri njem v času njegovega bivanja v vrtcu. Zato sta se svetovalni delavki spraševali, kakšna bo odslej njuna vloga pri ZO otrok. Ena je menila, da bi morali bolj izpostaviti svoje kompetence, ki jih imajo za delo $z$ otroki s posebnimi potrebami:

Mislim, da si zaslužimo večjo veljavo, recimo, ko imamo otroke $z$ avtizmom ali z motnjo pozornosti, smo za pripravo prilagoditev bolj kompetentni. [...] Mi vemo, kaj otrok v skupini potrebuje, da bo lažje funkcioniral, sledil skupini ... sprašujem se, koliko tega lahko zdravnik ali nekdo, ki vidi otroka redko, dà.

Svetovalni delavki sta poudarili tudi, da vidita izzive v sodelovanju z različnimi akterji, to je s strokovnimi delavci z različnih področij, ki bodo sodelovali 
$\checkmark$ večdisciplinarnem timu v okviru CZO. Pri tem sta poudarili, da bo treba posebno skrb nameniti ustvarjanju varnega okolja, v katerem bodo starši čutili, da lahko iskreno spregovorijo o težavah, ki jih sami zaznavajo oz. jih zaznavajo strokovni delavci pri njihovem otroku. Ena svetovalna delavka je povedala naslednje:

Sedaj, ko bodo sestanki drugje, je vprašanje, koliko bomo mi imeli možnost individualnega pogovora $s$ starši, mogoče bo tega manj. Hodili bomo na sestanke, na katerih bo prisotnih pet ljudi, vprašanje je, koliko bomo imeli mi priložnost in koliko se bodo starši odprli, da bodo iskali rešitve.

Svetovalna delavka je poudarila pomen sodelovanja z različnimi strokovnimi delavci tudi zaradi pretoka informacij; do sedaj srečanja s pediatri pogosto niso bila mogoča, zato se ena svetovalna delavka nadeja, da bo z novo organizacijo zagotavljanja celostne obravnave to mogoče:

Velikokrat smo dobili otroke, ki so imeli hude zdravstvene težave, kar je področje zdravstva, prišli so $v$ vrtec in mi o tem nismo nič vedeli. [...] Veliko časa smo se borili, da smo uspeli pripraviti tako zdravniško potrdilo (obrazec), $v$ katerem piše, ali je otrok usmerjen ali je obravnavan $v$ razvojni ambulanti. [...] Z novim zakonom naj bi bila povezava z zdravstvom boljša [...]. Upam, da bo steklo tako, kot je načrtovano, in da bo pretok informacij tudi v praksi stekel.

Sodelovanje v strokovnih (večdisciplinarnih) timih predstavlja pomembno kompetenco pedagoških delavcev v inkluziji (Borg idr. 2011) in ima pri zagotavljanju zgodnje obravnave otrok ključno vlogo (Soriano 2005), zato je pomembno, da se svetovalni delavci počutijo dovolj okrepljene za vstopanje $v$ enakovredno komunikacijo s strokovnjaki z različnih bolj ali manj sorodnih strokovnih področij. V tej vlogi ZOPOPP svetovalnih delavk trenutno ne krepi, saj njihove vloge ne opredeli jasno. Razumevanje lastne profesionalne vloge pa je ključnega pomena za posameznikovo angažirano delovanje, ki se odraža tudi v njegovi zmožnosti sodelovanja z drugimi (Pantić in Florian 2015).

\section{Sklep}

ZO se začne že v prenatalnem obdobju, zaključi pa z otrokovim vstopom v vrtec, zato imajo pri njenem udejanjanju pomembno vlogo tako vzgoja in izobraževanje (vrtec) kot zdravstvo. Vlogi vzgoje in izobraževanja pa morata 
biti prepletajoči in dopolnjujoči se glede na lastno področje kompetenc. Interakcije med omenjeni področji, ki so $v$ svojem delovanju kompleksna, so zapletene, a kljub temu lahko pomembno prispevajo k oblikovanju spodbudnega okolja za uspešen otrokov razvoj (Renn 2003). Pomen prepletanja medicinskega in socialno-pedagoškega vidika obravnave otrok s posebnimi potrebami in dela z njimi poudarja tudi D. Mitchell (2014). Fokus ZO je usmerjen $\checkmark$ različne vidike otrokovega socialno-čustveno-kognitivnega delovanja ter $v$ zagotavljanje ustreznih pogojev za otrokov razvoj (Fillis, Dunnea in McConnell 2018). Učinkovita ZO otrok s posebnimi potrebami ali posebnostmi v razvoju predvideva tudi pomoč in podporo njihovim družinam. Pri oblikovanju ZOPOPP so njegovi avtorji sledili sodobnim smernicam na področju ZO. Njegov temeljni namen pa je zagotoviti ustrezno in celostno obravnavo otrok, ki jo ti potrebujejo.

S študijo primera ugotavljamo, da trenutno še niso vzpostavljeni temeljni pogoji za njegovo uresničevanje, saj so prisotne različne dileme pa tudi izzivi, ker med drugim še niso sprejeti temeljni pravilniki in podzakonski akti, ki bi v celoti omogočali udejanjanje ZOPOPP. Nejasnosti se glede na mnenje svetovalnih delavk nanašajo predvsem na konkretno izvedbo ZOPOPP. Izziv zagotovo predstavlja tudi sodelovanje s starši, ki bodo od slej sodelovali s timom strokovnjakov v CZO in timom strokovnjakov v vrtcu. Po eni strani bo to staršem omogočilo, da dobijo poenoteno mnenje ter oceno otrokovega razvoja in njegovih potreb, po drugi strani pa se bodo morali strokovnjaki pri podajanju mnenja poenotiti, kar je do sedaj predstavljalo težavo. Pomembna prednost ZOPOPP je, da bo lahko več otrok dobilo ustrezno, predvsem pa pravočasno obravnavo, pri tem je vredno izpostaviti otroke s čustveno-vedenjskimi težavami, ki do sedaj v predšolskem obdobju niso imeli zagotovljene pravočasne in ustrezne obravnave. Z ZOPOPP pa so vrtci oz. njihove svetovalne delavke postavljene pred zahtevo, da deloma preoblikujejo svojo vlogo, predvsem pa da $v$ komunikacijo $z$ drugimi strokovnimi delavci (tudi z zdravstvenega področja) vstopajo kot strokovnjaki, ki imajo kompetence za detekcijo in identifikacijo otrok s posebnostmi v razvoju, delo z njimi in njihovimi starši ter izvajanje prilagoditev, ki otroku omogočajo polno vključenost v vrtčevsko skupino.

\section{Literatura}

Ainscow, M., T. Booth in A. Dyson. 2006. Improving Schools, Developing Inclusion. New York: Routledge.

Krek, J., in M. Metljak, ur. 2011. Bela knjiga o vzgoji in izobraževanju v Republiki Sloveniji. 2011. Ljubljana: Pedagoški inštitut. 
Blakemore, S. J., in U. Frith. 2005. The Learning Brain: Lessons for Education. Oxford: Blackwell.

Borg, G., J. Hunter, B. Sigurjónsottír in S. D’Alessio. 2011. Ključna načela za spodbujanje kakovostiv inkluzivnem izobraževanju. Bruselj: Evropska agencija za razvoj izobraževanja na področju posebnih potreb.

Bronfenbrenner, U. 1995. »Developmental Ecology Through Space and Time: Future Perspective."V Examining Lives in Context: Perspectives on Ecology of Human Development, ur. P. Moen, G. H. Elder in K. Luscher, 619-647. Washington, DC: American Psychological Association Press.

Fillis, S., L. Dunne in B. McConnell. 2018. »Empirical Studies on Early Intervention Services for Toddlers Aged 24-36 Months: A Systematic Review.«International Journal of Educational Research 89:119-138.

Globačnik, B. 2012. Zgodnja obravnava. Ljubljana: Zavod Republike Slovenije za šolstvo.

Karoly, L. A., M. R. Kilburn in J. S. Cannon. 2005. Early Childhood Interventions: Proven Results, Future Promise. Santa Monica, CA: Rand.

Koegel, L. K., R. L. Koegel, K. Ashbaugh in J. Bradshaw. 2014. »The Importance of Early Identification and Intervention for Children with or at Risk for Autism Spectrum Disorders."International Journal of Speech-Language Pathology 16 (1): 50-56.

Kyriacou, C. 2001. »Teacher Stress: Directions for Future Research.« Educational Review 53 (1): 27-35.

Majnemer, A. 1998. »Benefits of Early Intervention for Children with Developmental Disabilities. "Seminars in Pediatric Neurology 5 (1): 62-69.

Marjanovič Umek, L., in M. Zupančič, ur. 2009. Razvojna psihologija. Ljubljana: Znanstvena založba Filozofske fakultete.

McWilliam, R. A. 2010. Working with Families of Young Children with Special Needs. New York: Guilford.

Mitchell, D. 2014. What Really Works in Special and Inclusive Education: Using Evidence-Based Teaching Strategies. London: Routledge.

Nores, M., in W. S. Barnett. 2010. »Benefits of Early Childhood Interventions Across the World." Economics of Education Review 29 (2): 271-282.

Pantić, N., in L. Florian. 2015. »Developing Teachers As Agents of Inclusion and Social Justice.« Education Inquiry 6 (3): 333-351.

Porter, L. 2002. Educating Young Children with Special Needs. London: Paul Chapman.

Prater, L. P. 2010. »Parent and Family Involvement in the Education of Children with Special Needs. «V International Encyclopedia of Education, ur. P. Peterson, E. Baker in B. McGaw, 788-793. Oxford: Elsevier.

Renn, K. A. 2003. »Understanding the Identities of Mixed-Race College Students Through a Developmental Ecology." Journal of College Student Development 44 (3): 383-399. 
Simpson, C. G., in L. Warner. 2010. Successful Inclusion Strategies for Early Childhood Teachers. Waco, TX: Prufrock Press.

Slee, R. 2014. "Discourses of Inclusion and Exclusion: Drawing Wider Margins." Power and Education 6 (1): 7-17.

Soriano, V. (2005). Zgodnja obravnava v otroštvu: analiza stanja v Evropi; ključni vidiki in priporočila. Bruselj: Evropska agencija za razvoj izobraževanja na področju posebnih potreb.

Tschannen-Moran, M., in A. W. Woofolk Hoy. 2007. »The Differential Antecedents of Self-Efficacy Beliefs of Novice and Experienced Teachers."Teaching and Teacher Education 23 (6): 944-956.

Zakon o celostni zgodnji obravnavi predšolskih otrok s posebnimi potrebami (ZOPOPP). 2017. Uradni list Republike Slovenije, št. 17.

Zakon o usmerjanju otrok s posebnimi potrebami (ZUOPP-1). 2011. Uradni list Republike Slovenije, št. 58.

\section{Challenges of Early Intervention of Preschool Children}

A modern understanding of the early intervention of children originates from the Ecological Systems Theory that enables an in-depth identification of risk factors in the child's development and the environment. The purpose of early intervention is to ensure adequate prevention and a timely treatment of children with developmental delay, already in the earliest period of their life. At the beginning of 2019, the Act Regulating the Integrated Early Treatment of Preschool Children with Special Needs, which was supposed to fully regulate this area, came into force in Slovenia. We were interested in how kindergarten counsellors understand the importance of early intervention, what advantages and disadvantages they perceive in the Act, and how they see their role in it. We interviewed two counsellors. The findings indicate that the new Act brings many advantages in the field of early intervention, as well as challenges. The latter mainly concern the cooperation with various participants involved in early intervention. They emphasize that all the conditions for implementing the Act have not yet been guaranteed.

Keywords: counsellors, act, children with special needs, early intervention, kindergarten 